\title{
Diabetes Self-Care Activities (Diet \& Exercise) and Adherence to Treatment: A Hospital -Based Study among Diabetic Male Patients in Taif, Saudi Arabia
}

\author{
Abubaker Ibrahim Elbur
}

Pharmacy Practice Research Unit, College of Pharmacy, Taif University, Kingdom of Saudi Arabia

\begin{abstract}
Diabetes mellitus is a complex disorder that requires constant adherence to certain lifestyle measures and medication to achieve good glycaemic control. The main aim of this study was to measure adherence to self- care practices (diet, exercise and medication) among diabetic patients and to identify predicators of adherence. A hospitalbased study was conducted in King Abdul Aziz Specialized Hospital, Taif, KSA during June - October 2013. Convenient method of sampling was adopted, whereby all adult $(\geq 18$ years) male diabetic patients were recruited. Data was collected through face-to-face interview method using structured questionnaire. Data was processed using the software Statistical Package for Social Science (SPSS) (Version 21). Overall 378 patients were eligible; $191(50.5 \%)>50$ years old and nearly two third had secondary or university education. Overweight and obese patients constituted more than two third of the respondents. Generally adherence to diet, exercise was found to be low. Multivariate analysis showed that only presence of other diseases \{adjusted OR 2.8 (1.3-6.0), $\mathrm{P}=0.011$ \} and marital status \{adjusted OR 3.4 (1.011.7), $P=0.049\}$ were found to be significantly associated with adherence to diet. Patients' age was the only predicator for patients' commitment to practicing exercise \{adjusted OR 4.7(1.3-17.8), $P=0.020)$. Non adherence to medication was found to $80.6 \%(n=305)$. In conclusion non-adherence to the studied self-care practices was suboptimal. Proper and continuous health education accompanied with patients' motivation may improve patients' adherence.
\end{abstract}

Keywords: Diabetes, self-care activities, diet, exercise, medication, adherence.

\section{INTRODUCTION}

The prevalence of diabetes is high among the Saudi population and represents a major clinical and public health problem [1]. Diabetes mellitus is a complex disorder that requires constant adherence to certain lifestyle measures and medication to achieve good glycaemic control [2].

Self-care management was defined as "an evolutionary process of development of knowledge or awareness by learning to survive with the complex nature of the diabetes in a social context" $[3,4]$. In diabetic patients there are seven essential self-care behaviors associated with good clinical outcome. These are healthy eating, being physically active, monitoring of blood sugar, adherence to medications, good problem-solving skills, healthy coping skills and risk-reduction behaviors [5]. Several demographic, psychological, social, health care provider and medical system, and disease- and treatment-related factors potentially related to patients compliance [6].

Several studies conducted a round the world showed that adherence to self-care practices was suboptimal. Zhou et al. [7] identified deficits in diabetes related knowledge and self-care practices among the

*Address correspondence to this author at the Pharmacy Practice Research Unit, College of Pharmacy, Taif University, P.O. Box: 888, 21974; Al-Haweiah, Taif, Kingdom of Saudi Arabia; Tel: +966541399649;

E-mail: bakarelbu@yahoo.co.uk majority of patients with uncontrolled blood glucose. Researchers found that knowledge of diabetes selfcare and knowledge of cardiovascular complications increase as the knowledge of diabetes increases [8]. Thomas et al. [9] identified perceived difficulty taking part in exercise, feelings of tiredness, lack of time and lack of local facilities as main reasons for non adherence to exercise among diabetic patients. Barriers to adherence to healthy diet include; the cost, small portion sizes, support and family issues and quality of life and lifestyle issues [10].

Although researches have been published on selfcare practices from different regions there is a limited data available on this topic in Saudi Arabia. Assessing patients self-care behaviors and identification of the factors that influence no-adherence to these practices will help in the designing of interventions aimed at improving patients clinical outcomes. Therefore, this study was conducted to measure adherence to selfcare practices (diet, exercise and medication) and to identify patients, background factors associated with adherence to these behaviors among patients with type -2 diabetes.

\section{METHODS}

A cross- sectional hospital-based study was conducted in King Abdul Aziz Specialized Hospital, Taif, KSA during June - October 2013. Convenient method of sampling was adopted, whereby all adult $(\geq$ 
18 years) male diabetic patients on medical treatment were recruited. Verbal informed consent was obtained. Newly diagnosed patients and those who refused to participate were excluded. Data was collected through face-to-face interview method using structure questionnaire. The questionnaire was divided into three parts. The first part was designed to collect data on patients' background characteristics (age, residence, marital status, employment status, educational level, monthly income, presence of other disease, time since diagnosed with diabetes, type of current medication). The WHO classification of BMI was used to classify the patients as underweight (BMI $<18.5 \mathrm{~kg} / \mathrm{m}^{2}$ ), normal (BMI 18.5-24.9 kg/ m²), overweight (BMI $25.0-29.9 \mathrm{~kg} /$ $\mathrm{m}^{2}$ ), and obese (BMI $\geq 30 \mathrm{~kg} / \mathrm{m}^{2}$ ) [11]. Part two of the questionnaire was composed of four questions to investigate the patients' self-care activities (general diet 2 questions and exercise 2 questions) derived from the questionnaire developed by Toobert et al. [12] (Summary of Diabetes Self-Care Activities - (SDSCA). The Arabic translation of these questions was done previously by Aljohani [13]. The translation process was done through standardized methodology and tested for reliability and validity by the same author in another part of the country. Patients were considered adherent to healthy diet if admitted adherence for seven days and non-adherent if they did not. In practicing specific exercise or participating in 30 minutes physical activity the patients were considered adherent to this measure if they admitted participation for $\geq 5$ days and non-adherent if they did this activity for $<5$ days. Part three was designed to assess patients' adherence to treatment. Medication nonadherence was measured using the self-reported 4item Morisky scale [14] which assesses patients' forgetfulness about taking medications, carelessness about taking medications, stopping medication when feeling better and stopping medication when feeling worse. Questions were answered as 'yes' and 'no' and scored one point for 'yes' and zero point for a 'no' response. Scores were summed to give total score, ranging from 0 to 4 . Non-adherence was defined as a score greater than zero.

Data was processed using the software Statistical Package for Social Science (SPPS) (Version 21). Descriptive statistics were used to describe all variables. Mean and standard deviation (SD) were calculated for continuous variables. Frequency and percentage were calculated for categorical variables. Patients' background characteristics which showed significant association on bivariate analysis with both diet and exercise activities were fitted into multiple logistic regression model to determine the independent predicators for the studied diabetes self -care practices. $P$ values of $<0.05$ were considered statistically significant.

\section{RESULTS}

\subsection{Patients' Background Characteristics}

Overall 378 patients were eligible; of them 219 $(57.9 \%)$ aged $40-65$ years and $61(16.1 \%)$ were $>65$ years. Patients who were living in the town were 307 $(81.2 \%)$ and nearly two third had either secondary or

Table 1: Patients' Background Characteristics

\begin{tabular}{|c|c|c|}
\hline Background characteristic & Frequency & Percent \\
\hline $\begin{array}{l}\leq 50 \text { years } \\
>50 \text { years }\end{array}$ & $\begin{array}{l}187 \\
191\end{array}$ & $\begin{array}{l}(49.5 \%) \\
(50.5 \%)\end{array}$ \\
\hline $\begin{array}{l}\text { Residence } \\
\text { Town } \\
\text { Outside town }\end{array}$ & $\begin{array}{c}307 \\
71\end{array}$ & $\begin{array}{l}(81.2 \%) \\
(18.8 \%)\end{array}$ \\
\hline $\begin{array}{c}\text { Body mass index }\left(\mathbf{k g} / \mathbf{m}^{2}\right) \\
\text { Underweight } \\
\text { Normal } \\
\text { Overweight } \\
\text { Obese }\end{array}$ & $\begin{array}{c}6 \\
118 \\
158 \\
96\end{array}$ & $\begin{array}{l}(1.6 \%) \\
(31.2 \%) \\
(41.8 \%) \\
(25.4 \%)\end{array}$ \\
\hline $\begin{array}{r}\text { Marital status } \\
\text { Married } \\
\text { Unmarried } \\
\end{array}$ & $\begin{array}{c}283 \\
95 \\
\end{array}$ & $\begin{array}{l}(74.9 \%) \\
(25.1 \%)\end{array}$ \\
\hline $\begin{array}{l}\text { Educational level } \\
\text { Secondary \& above } \\
\text { Below secondary }\end{array}$ & $\begin{array}{l}248 \\
130 \\
\end{array}$ & $\begin{array}{l}(65.6 \%) \\
(34.4 \%) \\
\end{array}$ \\
\hline $\begin{array}{r}\text { Employment status } \\
\text { Working } \\
\text { Not working }\end{array}$ & $\begin{array}{l}198 \\
180\end{array}$ & $\begin{array}{l}(52.4 \%) \\
(47.6 \%)\end{array}$ \\
\hline $\begin{array}{c}\text { Level of income (SR) } \\
<5000 \\
5000-10000 \\
>10000\end{array}$ & $\begin{array}{c}128 \\
159 \\
91\end{array}$ & $\begin{array}{l}(33.9 \%) \\
(42.1 \%) \\
(24.1 \%)\end{array}$ \\
\hline $\begin{array}{l}\text { Smoking } \\
\text { Smoker } \\
\text { Non-smoker } \\
\text { Ex-smoker }\end{array}$ & $\begin{array}{c}101 \\
191 \\
86\end{array}$ & $\begin{array}{l}(26.7 \%) \\
(50.5 \%) \\
(22.8 \%)\end{array}$ \\
\hline $\begin{array}{r}\text { Co-morbidity } \\
\text { Yes } \\
\text { No }\end{array}$ & $\begin{array}{l}205 \\
173\end{array}$ & $\begin{array}{l}(54.2 \%) \\
(45.8 \%)\end{array}$ \\
\hline $\begin{array}{c}\text { Duration of diabetes } \\
\qquad 5 \text { year } \\
>5 \text { years }\end{array}$ & $\begin{array}{l}128 \\
250\end{array}$ & $\begin{array}{l}(33.9 \%) \\
(66.1 \%)\end{array}$ \\
\hline $\begin{array}{c}\text { Type of medication } \\
\text { Oral hypoglycemic } \\
\text { Insulin } \\
\text { Combined }\end{array}$ & $\begin{array}{c}179 \\
124 \\
75\end{array}$ & $\begin{array}{l}(47.4 \%) \\
(32.8 \%) \\
(19.8 \%)\end{array}$ \\
\hline Total & 378 & 100 \\
\hline
\end{tabular}


university education. Patients suffering from other chronic diseases were $205(54.2 \%)$, of them 173 $(84.4 \%)$ were hypertensives and 110 (53.7\%) were hyperlipidemics. Regarding body mass index, overweight and obese patients constituted more than two third of the respondents. Obesity significantly increased with patients' age $(P=0.011)$, in married more than single $(P=0.004)$ and among patients suffering from other chronic diseases $(P=0.010)$. Nearly two third of the patients diagnosed with diabetes for > 10 years and $179(47.4 \%)$ were on oral hypoglycemic agents. Table 1 shows patients' background characteristics.

\subsection{Diabetes Self-Care Activities}

Responding to the question "on average over the past month, how many days per week you followed your eating plan", out of the patients 327 (86.5\%) admitted that their adherence was $<7$ days and only $51(13.5 \%)$ complied for 7 days \{mean number of days $2.65 \pm(2.48)\}$.

Out of the patients $344(91.0 \%)$ over the last week adhered to a healthy eating plan for $\leq 7$ days, compared to only $34(9.0 \%)$ admitted adherence for 7 days, \{mean number of days $2.07 \pm$ (2.33)\}.

As shown in Tables 2 \& 3 on bivariate analysis multiple patients' background characteristics were found to be significantly associated with adherence to healthy eating plan for seven days during the last month or during the last seven days. However; on multivariate analysis only presence of other diseases \{adjusted OR 2.8 (1.3-6.0), $\mathrm{P}=0.011\}$ and marital status \{adjusted OR $3.4(1.0-11.7), P=0.049\}$ were found to be significantly associated with following a healthy eating plan for seven days during the last month and adherence to healthful eating plan during the last seven days respectively.

Regarding participation in at least 30 minutes of physical activities during the last seven days, 274 $(72.5 \%)$ of the patients practiced this activity for $<5$ days compared to $104(27.5 \%)$ admitted $\geq 5$ days participation, \{mean number of days $2.64 \pm(2.48)\}$. Out of the patients $357(94.4 \%$ ) did not participated in a specific exercise session during the last seven days compared to only $21(5.6 \%)$ did this activity for $>5$ days

Table 2: Predicators of Following a Healthful Eating Plan for Seven Days During the Last Month

\begin{tabular}{|c|c|c|c|c|c|c|c|}
\hline $\begin{array}{l}\text { Background } \\
\text { characteristic }\end{array}$ & \multicolumn{2}{|c|}{$\begin{array}{l}\text { Following a healthful eating } \\
\text { plan during the last month }\end{array}$} & $n$ & $\begin{array}{c}\begin{array}{c}\text { Univariable } \\
\text { analysis }\end{array} \\
\begin{array}{c}\text { Crude OR }(95 \% \\
\mathrm{CI})\end{array}\end{array}$ & $\begin{array}{c}P \\
\text { value }\end{array}$ & $\begin{array}{c}\text { Multi- } \\
\text { variable } \\
\text { analysis } \\
\text { Adjusted } \\
\text { OR }(95 \% \mathrm{Cl})\end{array}$ & $\begin{array}{c}P \\
\text { value }\end{array}$ \\
\hline $\begin{array}{l}\leq 50 \text { years } \\
>50 \text { years }\end{array}$ & $\begin{array}{l}93.0 \\
80.1\end{array}$ & $\begin{array}{c}7.0 \\
19.9\end{array}$ & $\begin{array}{l}187 \\
191\end{array}$ & $\begin{array}{c}1 \\
3.3(1.7-6.8)\end{array}$ & 0.000 & & \\
\hline $\begin{array}{l}\text { Residence } \\
\text { Town } \\
\text { Outside town }\end{array}$ & $\begin{array}{l}88.6 \\
77.5\end{array}$ & $\begin{array}{l}11.4 \\
22.5\end{array}$ & $\begin{array}{c}307 \\
71\end{array}$ & $\begin{array}{c}1 \\
2.3(1.2-4.4)\end{array}$ & 0.015 & & \\
\hline $\begin{array}{l}\text { Marital status } \\
\text { Unmarried } \\
\text { Married }\end{array}$ & $\begin{array}{l}92.6 \\
84.5\end{array}$ & $\begin{array}{c}7.4 \\
15.5\end{array}$ & $\begin{array}{c}95 \\
283\end{array}$ & $\begin{array}{c}1 \\
2.3(1.0-5.3)\end{array}$ & 0.049 & & \\
\hline $\begin{array}{r}\text { Employment status } \\
\text { Working } \\
\text { Not working }\end{array}$ & $\begin{array}{l}89.4 \\
83.3\end{array}$ & $\begin{array}{l}10.6 \\
16.7\end{array}$ & $\begin{array}{l}198 \\
180\end{array}$ & $\begin{array}{c}1 \\
1.7(0.9-3.0)\end{array}$ & 0.087 & & \\
\hline $\begin{array}{l}\text { Co-morbidity } \\
\qquad \begin{array}{r}\text { No } \\
\text { Yes }\end{array}\end{array}$ & $\begin{array}{c}94.2 \\
180\end{array}$ & $\begin{array}{c}5.8 \\
20.0\end{array}$ & $\begin{array}{l}173 \\
205\end{array}$ & $\begin{array}{c}1 \\
4(2.0-8.4)\end{array}$ & 0.000 & $\begin{array}{c}1 \\
2.8(1.3-6.0)\end{array}$ & 0.011 \\
\hline $\begin{array}{l}\text { Duration of diabetes } \\
\qquad \begin{array}{c}\leq 5 \text { year } \\
>5 \text { years }\end{array}\end{array}$ & $\begin{array}{l}91.4 \\
84.0\end{array}$ & $\begin{array}{c}8.6 \\
16.0\end{array}$ & $\begin{array}{l}128 \\
250\end{array}$ & $\begin{array}{c}1 \\
2(1.0-4.1)\end{array}$ & 0.050 & & \\
\hline
\end{tabular}


Table 3: Predicators of Following a Healthful Eating Plan During the Last Seven Days

\begin{tabular}{|c|c|c|c|c|c|c|c|}
\hline \multirow[t]{2}{*}{$\begin{array}{l}\text { Background } \\
\text { characteristic }\end{array}$} & \multicolumn{2}{|c|}{$\begin{array}{l}\text { Following a healthful eating } \\
\text { plan during the last seven } \\
\text { days }\end{array}$} & \multirow[t]{2}{*}{$\mathbf{n}$} & \multicolumn{2}{|c|}{ Univariable analysis } & \multicolumn{2}{|c|}{ Multivariable analysis } \\
\hline & $<7$ days & 7days & & Crude OR (95\% Cl) & $P$ value & $\begin{array}{c}\text { Adjusted } \\
\text { OR }(95 \% \mathrm{Cl})\end{array}$ & $P$ value \\
\hline $\begin{array}{l}\text { Age } \\
\qquad \begin{array}{l}\leq 50 \text { years } \\
>50 \text { years }\end{array}\end{array}$ & $\begin{array}{l}94.7 \\
87.4\end{array}$ & $\begin{array}{c}5.3 \\
12.6\end{array}$ & $\begin{array}{l}187 \\
191\end{array}$ & $\begin{array}{c}1 \\
2.5(1.2-5.5)\end{array}$ & 0.017 & & \\
\hline $\begin{array}{l}\text { Residence } \\
\text { Town } \\
\text { Outside town }\end{array}$ & $\begin{array}{l}90.9 \\
91.5\end{array}$ & $\begin{array}{l}9.1 \\
8.5\end{array}$ & $\begin{array}{c}307 \\
71\end{array}$ & $\begin{array}{c}1 \\
0.9(0.4-2.3)\end{array}$ & 0.859 & & \\
\hline $\begin{array}{r}\text { Marital status } \\
\text { Single } \\
\text { Married }\end{array}$ & $\begin{array}{l}96.8 \\
89.0\end{array}$ & $\begin{array}{c}3.2 \\
11.0\end{array}$ & $\begin{array}{c}95 \\
283\end{array}$ & $\begin{array}{c}1 \\
3.8(1.1-12.6)\end{array}$ & 0.031 & $\begin{array}{c}1 \\
3.4(1.0-11.7)\end{array}$ & 0.049 \\
\hline $\begin{array}{l}\text { Educational level } \\
\quad \geq \text { Secondary } \\
<\text { secondary }\end{array}$ & $\begin{array}{l}94.0 \\
85.4\end{array}$ & $\begin{array}{c}6.0 \\
14.6\end{array}$ & $\begin{array}{l}248 \\
130\end{array}$ & $\begin{array}{c}1 \\
2.7(1.3-5.4)\end{array}$ & 0.007 & & \\
\hline $\begin{array}{c}\text { Employment status } \\
\text { Working } \\
\text { Not working }\end{array}$ & $\begin{array}{l}193.9 \\
87.8\end{array}$ & $\begin{array}{c}6.1 \\
12.2\end{array}$ & $\begin{array}{l}198 \\
180\end{array}$ & $\begin{array}{c}1 \\
2.2(1.0-4.5)\end{array}$ & 0.040 & & \\
\hline $\begin{array}{l}\text { Co-morbidity } \\
\qquad \begin{array}{r}\text { No } \\
\text { Yes }\end{array}\end{array}$ & $\begin{array}{l}94.8 \\
87.8\end{array}$ & $\begin{array}{c}5.2 \\
12.2\end{array}$ & $\begin{array}{l}173 \\
205\end{array}$ & $\begin{array}{c}1 \\
2.5(1.1-5.6)\end{array}$ & 0.021 & & \\
\hline $\begin{array}{l}\text { Duration of diabetes } \\
\qquad 5 \text { year } \\
>5 \text { years }\end{array}$ & $\begin{array}{l}91.4 \\
84.0\end{array}$ & $\begin{array}{c}8.6 \\
16.0\end{array}$ & $\begin{array}{l}128 \\
250\end{array}$ & $\begin{array}{c}1 \\
1.3(0.6-2.7)\end{array}$ & 0.566 & & \\
\hline
\end{tabular}

Table 4: Predicators of Participation in at Least 30 Minutes of Physical Activity

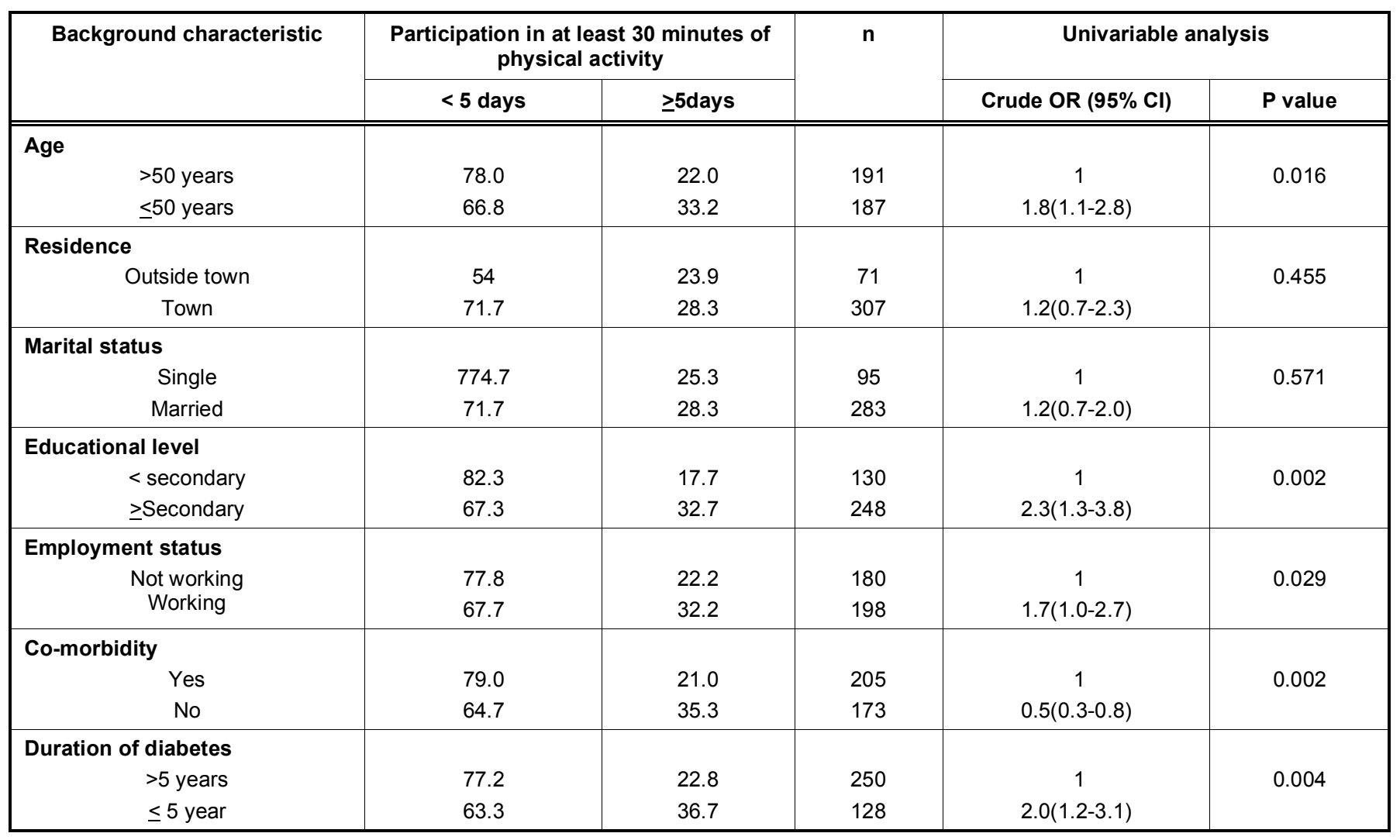


Table 5: Predicators of Participation in a Specific Exercise Session

\begin{tabular}{|c|c|c|c|c|c|c|c|}
\hline \multirow[t]{2}{*}{$\begin{array}{l}\text { Background } \\
\text { characteristic }\end{array}$} & \multicolumn{2}{|c|}{$\begin{array}{l}\text { Participation in a specific } \\
\text { exercise session }\end{array}$} & \multirow[t]{2}{*}{ Total } & \multicolumn{2}{|c|}{ Univariable analysis } & \multicolumn{2}{|c|}{ Multivariable analysis } \\
\hline & $<5$ day & $\geq 5$ days & & $\begin{array}{c}\text { Crude OR }(95 \% \\
\text { Cl) }\end{array}$ & $P$ value & $\begin{array}{c}\text { Crude OR }(95 \% \\
\text { CI) }\end{array}$ & $P$ value \\
\hline $\begin{array}{l}\text { Age } \\
\qquad \begin{array}{l}>50 \text { years } \\
\leq 50 \text { years }\end{array}\end{array}$ & $\begin{array}{l}98.4 \\
90.4\end{array}$ & $\begin{array}{l}1.6 \\
9.6\end{array}$ & $\begin{array}{l}191 \\
187\end{array}$ & $\begin{array}{c}1 \\
6.7(1.9-23.0)\end{array}$ & 0.003 & $\begin{array}{c}1 \\
4.7(1.3-17.8)\end{array}$ & 0.020 \\
\hline $\begin{array}{r}\text { Marital status } \\
\text { Single } \\
\text { Married }\end{array}$ & $\begin{array}{l}90.5 \\
95.8\end{array}$ & $\begin{array}{l}9.5 \\
4.2\end{array}$ & $\begin{array}{c}95 \\
283\end{array}$ & $\begin{array}{c}1 \\
0.4(0.2-1.0)\end{array}$ & 0.06 & & \\
\hline $\begin{array}{c}\text { Employment status } \\
\text { Not working } \\
\text { Working }\end{array}$ & $\begin{array}{l}96.1 \\
92.9\end{array}$ & $\begin{array}{l}3.9 \\
7.1\end{array}$ & $\begin{array}{l}180 \\
198\end{array}$ & $\begin{array}{c}1 \\
1.9(0.7-4.8)\end{array}$ & 0.184 & & \\
\hline $\begin{array}{r}\text { Co-morbidity } \\
\text { No } \\
\text { Yes }\end{array}$ & $\begin{array}{l}90.8 \\
97.6\end{array}$ & $\begin{array}{l}9.2 \\
2.4\end{array}$ & $\begin{array}{l}173 \\
205\end{array}$ & $\begin{array}{c}1 \\
0.2(0.1-0.7)\end{array}$ & 0.007 & & \\
\hline $\begin{array}{l}\text { Duration of diabetes } \\
\qquad \begin{array}{l}>5 \text { years } \\
\leq 5 \text { year }\end{array}\end{array}$ & $\begin{array}{l}96.0 \\
91.4\end{array}$ & $\begin{array}{l}14.0 \\
8.6\end{array}$ & $\begin{array}{l}250 \\
128\end{array}$ & $\begin{array}{c}1 \\
2.3(0.9-5.5)\end{array}$ & 0.07 & & \\
\hline
\end{tabular}

per week. Similarly on bivariate analysis multiple patients' background were found to be significantly associated with practicing exercise as a self-care measure and patients' background characteristics as shown in Tables 4 \& 5 . Multivariate analysis showed that patients' age was the only predicator for patients' commitment to practicing exercise \{adjusted OR 4.7(1.3-17.8), $P=0.020)$.

The prevalence of non adherence to medication was found to $80.6 \%(n=305)$. No single patients' background variable was found to be associated with patient's compliance to treatment.

\section{DISCUSSION}

The results of demographic characteristics of the recruited patients in the current study revealed that younger and middle-aged are mostly affected with diabetes than elderly ones. In a survey conducted to determine the prevalence of diabetes among Saudi population, the mean (SD) age for onset of diabetes in males was found to be 57.5 (13.1) years [15]. Generally Asians develop diabetes at younger ages compared to Western populations [16].
Nearly $80 \%$ of the recruited patients were permanently residents in the city. The increased prevalence of diabetes was found to be associated with migration and urbanization. For example; among Omani population a high prevalence of diabetes, obesity, hypertension and high cholesterol was documented, particularly among urban-dwellers and older individuals [17]. In contrary to these findings a recent study conducted among Greenland Inuit impaired fasting glycaemia was found to be low among urban population [18].

In Saudi Arabia, obesity is becoming one of the most important public health problems [19]. Overweight and obesity affect more than $75 \%$ of the total population in Saudi Arabia [20]. Among adult Saudi male; middle age, lower education and joblessness were found to important predicators for obesity [21]. Slightly $>25 \%$ of the patients participated in the study were obese and $>40 \%$ of them was classified as overweight. In contrary to this finding Ayele et al. [22] reported low rate of obesity (5.9\%) and overweight $(27.0 \%)$ among diabetic Ethiopian patients. The observed variation in the results between the two 
studies may be attributed to the difference in socioeconomic status between the populations in the two countries.

Another important finding was the coexistence of hypertension and diabetes among $>45 \%$ of participants. Salman \& Al-Rubeaan [23] investigated the incidence of hypertension and associated factors In Saudi with type 2 diabetes patients. They identified incidence rate of 17.2/100 person-years, with older age, male gender, higher BMI, diabetes duration of $<5$ years and retinopathy being strong predicators of hypertension development.

Diabetic patient at increased risk of cardiovascular disease (2- to 3-fold) compared with non diabetic ones with dyslipidemia one of the major risk factors contributing to the increased incidence of these diseases [24]. Nearly $30 \%$ of the participants were suffering from hyperlipidemia.

The prime aim of this study was to measure self care practices; diet, exercise and adherence to treatment plan. Self report approach was adopted in this study to investigate the three domains as it is practical and cost-effective method despite it is often seen as undependable [25]. Overall patients' adherence to the three studied self- care practices was worse.

Researches proved significant association between patients' compliance status to healthy diet and fasting blood sugar [26]. The results showed that only $13.5 \%$ complied for 7 days during the last month to their eating plan $\{$ mean number of days $2.65 \pm(2.48)\}$ and $9.0 \%$ of them admitted adherence for 7 days in the last week, \{mean number of days $2.07 \pm$ (2.33)\}. In contrast Guo et al. [27] among Chinese diabetic patients reported a high mean number of days [4.86 $\pm(2.18)]$ adherence to general diet with significant difference between patient with diabetes education and those who were not educated about the disease. Non-adherence to dietary requirement may be attributed to poor selfdiscipline, lack of information and tendency to eat out [28]. Multivariable analysis showed that adherence to general diet was significantly associated with coexistence of hypertension and hyperlipidemia. This was considered as a positive finding. Adherence to diet may help in controlling these diseases with the consequence of reduction in the rate of morbidity and mortality associated with these abnormalities. Similarly Tol et al. [29] noted a significant relation between adherence to diet and co-morbidity among other factors. Family and social support are important aspects of adherence to diabetes management [30]. In the current study patients' marital status was also identified as a predictor to adherence to diet. Comparatively in the above mentioned study [29] no relation was noted between marital status and adherence to self-care practices.

Aerobic and resistance training performed regularly have many benefits as it acutely improve insulin action, help in the management of blood glucose levels, lipids, blood pressure, decrease the cardiovascular risk, decrease mortality rate, and increase the quality of life [31]. The results obtained in the current research showed that to some extent participation in at least 30 minutes of physical activity was better than participation in a specific exercise session. Comparatively Nelson et al. [32] reported no regular physical activity among $31 \%$ of individuals with type 2 diabetes and $38 \%$ less than recommended levels of physical activity. The only factor that was found to be associated with participation in specific exercise session was patients' age, as patients $<50$ years were nearly five times practiced this activity compared to $>$ 50 years aged ones. In contrary to this in another recent study younger were found to be less adherent to healthy diet, medication intake, blood glucose checking, foot care and exercise compared to older patients [33].

The results of the assessment of patients 'adherence to the prescribed treatment in the current study showed that non-adherence was prevalent among $80.6 \%$ of the interviewed patients, with no significant association between patients' background characteristics and adherence to treatment. In contrast, other researchers identified association of several factors with patients' compliance to treatment; like increasing age, male gender, education, low level of monthly income and a longer duration of diabetes [34]. The variations in the results between the two studies may be attributed to the difference in the methods used for assessment of patients' compliance or due to the difference in the background characteristics of the studied populations.

Analysis of the association of patients' factors and how it affects their adherence to self -care practices is important. However, the influence of others factors cannot be ignored. In the hospital where the study was conducted, the specialized health care services were expected to be accompanied with proper health education. This is important as researchers found that diabetic patients who received specialist care reported 
better self- care practices better than those received generalist care [35].

There were some limitations in the study. The study sample was recruited from one hospital and only males were interviewed this limit the generalizability of the result to the entire diabetic population. Future researched may include representative sample diabetics from all regions in the country. Patients' adherence to self- care practices were obtained by self report method, this may subject the data to recall bias.

\section{CONCLUSION}

This study demonstrated that non-adherence to the studied self-care practices; diet, exercise and adherence to medication were suboptimal. Marital status and co-existence of hypertension and hyperlipidemia were found to be associated with adherence to diet, while adherence to exercise was associated significantly with younger age. Proper and continuous health education accompanied with patients' motivation is needed to increase the level of commitment to the studied self-care activities.

\section{ACKNOWLEDGEMENTS}

The author would like to thank Mohammed Abdullah Alshuqayhi, Waleed Abed Althomali and Ali Abdullah Aljoaid; Final Year Pharm D students; College of Pharmacy, Taif University for the great effort done in data collection. Also especial thanks go to the staff of King Abdul Aziz Specialized Hospital, Taif, KSA for cooperation.

\section{REFERENCES}

[1] Shaw JE, Sicree RA, Zimmet PZ. Global estimates of the prevalence of diabetes for 2010 and 2030. Diabetes Res Clin Pract 2010; 87: 4-14. http://dx.doi.org/10.1016/j.diabres.2009.10.007

[2] Alqurashi KA, Aljabri KS, Bokhari SA. Prevalence of diabetes mellitus in a Saudi community. Ann Saudi Med 2011; 31: 1923.

\section{http://dx.doi.org/10.4103/0256-4947.75773}

[3] Cooper H, Booth K, Gill G. Patients' perspectives on diabetes health care education. Health Educ Res 2003; 18: 191-206. http://dx.doi.org/10.1093/her/18.2.191

[4] Paterson B, Thorne S. Developmental evolution of expertise in diabetes self management. Clin Nurs Res 2000; 9: 402419.

http://dx.doi.org/10.1177/10547730022158663

[5] American Association of Diabetes Educators: AADE7 SelfCare Behaviors. Diabet Educ 2008; 34: 445-449. http://dx.doi.org/10.1177/0145721708316625

[6] Delamater AM. Improving Patient Adherence. Clin Diabet 2006; 24: 71-77. http://dx.doi.org/10.2337/diaclin.24.2.71

[7] Zhou Y, Liao L, Sun M, He G. Self-care practices of Chinese individuals with diabetes. Exp Ther Med 2013; 5: 1137-1142.
Adibe M, Aguwa C. Diabetes self-care knowledge among type 2 diabetic outpatients in south-eastern Nigira. Int J Drug Develop Res 2009; 1: 85-104.

[9] Thomas N, Alder E, Leese G P. Barriers to physical activity in patients with diabetes. Postgrad Med J 2004; 80: 287-291. http://dx.doi.org/10.1136/pgmj.2003.010553

[10] Vijan S, Stuart NS, Fitzgerald JT, et al. Barriers to following dietary recommendations in type 2 diabetes. Diabet Med 2005; 22: 32-38.

http://dx.doi.org/10.1111/j.1464-5491.2004.01342.x

[11] World Health Organization. Physical status: The use and interpretation of Anthropometry 1995. Report of a WHO Expert Committee. WHO Technical Report Series 854. World Health Organization, Geneva.

[12] Toobert DJ, Hampson SE, Glasgow RE. The summary of diabetes self-care activities measure: results from 7 studies and a revised scale. Diabet Care 2000; 23: 943-950.

http://dx.doi.org/10.2337/diacare.23.7.943

[13] Aljohani, Khalid A. Factors affecting the self-management practices of people with type 2 diabetes in Almadinah, Saudi Arabia. Ph.D. Curtin University, School of Nursing and Midwifery 2011.

[14] Morisky DE, Green LW, Levine DM. Concurrent and predictive validity of a self-reported measure of medication adherence. Med Care 1986; 24: 67-74.

http://dx.doi.org/10.1097/00005650-198601000-00007

[15] Alqurashi KA, Aljabri KS, Bokhari SA. Prevalence of diabetes mellitus in a Saudi community. Ann Saudi Med 2011; 31: 1923.

http://dx.doi.org/10.4103/0256-4947.75773

[16] Hu FB. Globalization of diabetes the role of diet, lifestyle, and genes. Diabet Care 2011; 34: 1249-1257.

http://dx.doi.org/10.2337/dc11-0442

[17] Al-Moosa S, Allin S, Jemiai $\mathrm{N}$, et al. Diabetes and urbanization in the Omani population: an analysis of national survey data. Popul Health Metr 2006; 24: 4: 5.

[18] Jørgensen ME, Borch-Johnsen K, Witte DR, Bjerregaard P. Diabetes in Greenland and its relationship with urbanization. Diabet Med 2012; 29: 755-60. http://dx.doi.org/10.1111/j.1464-5491.2011.03527.x

[19] Madani KA, Al-Amoudi NS, Kumosani TA. The state of nutrition in Saudi Arabia. Nutr Health 2000; 14: 17-31. http://dx.doi.org/10.1177/026010600001400103

[20] Al-Shehri FS, Moqbel MM, Al-Shahrani AM, et al. Management of obesity: Saudi Clinical Guideline. Saudi J Obesity 2013; 1 : 18-30. http://dx.doi.org/10.4103/2347-2618.119472

[21] Al-Shammari SA, Khoja TA, Al-Maatoug MA. The prevalence of obesity among Saudi males in the Riyadh Region. Ann Saudi Med 1996; 16: 269-73.

[22] Ayele K, Tesfa B, Abebe L, et al. Self Care Behavior among Patients with Diabetes in Harari, Eastern Ethiopia: The Health Belief Model Perspective. PLoS One 2012; 7(4): e35515.

http://dx.doi.org/10.1371/journal.pone.0035515

[23] Salman RA, Al-Rubeaan KA. Incidence and risk factors of hypertension among Saudi type 2 diabetes adult patients: an 11-year prospective randomized study. J Diabet Complicat 2009; 23: 95-101.

http://dx.doi.org/10.1016/j.jdiacomp.2007.10.004

[24] Goldberg RB. Hyperlipidemia and cardiovascular risk factors in patients with type 2 diabetes. Am J Manag Care 2000; 6(13 Suppl): S682-91.

[25] Shrivastava SR, Shrivastava PS, Ramasamy J. Role of selfcare in management of diabetes mellitus. J Diabetes Metab Disord 2013; 12: 14 http://dx.doi.org/10.1186/2251-6581-12-14

[26] Tan SL, Juliana S, Sakinah H. Dietary compliance and its association with glycemic control among poorly controlled 
type 2 diabetic outpatients in Hospital Universiti Sains Malaysia. Malays J Nutr 2011; 17: 287-99.

[27] Guo XH, Yuan L, Lou QQ, et al. Chinese Diabetes Education Status Survey Study Group. A nationwide survey of diabetes education, self-management and glycemic control in patients with type 2 diabetes in China. Chin Med J (Engl) 2012; 125: 4175-80.

[28] Ganiyu AB, Mabuza LH, Malete NH, et al. Non-adherence to diet and exercise recommendations amongst patients with type 2 diabetes mellitus attending Extension II Clinic in Botswana. Afr J Primary Health Care \& Family Med 2013; 5: 6. doi: 10.4102/phcfm.v5i1.457.

[29] Tol A, Shojaeezadeh D, Eslami A, et al. Evaluation of selfcare practices and relative components among type 2 diabetic patients. J Educ Health Promot 2012; 1: 19. http://dx.doi.org/10.4103/2277-9531.99219

[30] Miller TA, Dimatteo MR. Importance of family/social support and impact on adherence to diabetic therapy. Diabet Metab Syndr Obes 2013; 6: 421-426. http://dx.doi.org/10.2147/DMSO.S36368

[31] Colberg SR, Sigal RJ, Fernhall B, et al. Exercise and type 2 diabetes: the American College of Sports Medicine and the
American Diabetes Association: joint position statement. Diabet Care 2010; 33: e147-67. doi: 10.2337/dc10-9990.

[32] Nelson KM, Reiber G, Boyko EJ, NHANES III. Diet and exercise among adults with type 2 diabetes: findings from the third national health and nutrition examination survey (NHANES III). Diabet Care 2002; 25: 1722-8. http://dx.doi.org/10.2337/diacare.25.10.1722

[33] Chourdakis M, Kontogiannis V, Malachas K, et al. Self-Care Behaviors of Adults with Type 2 Diabetes Mellitus in Greece. $\mathrm{J}$ Community Health 2014. [Epub ahead of print]. http://dx.doi.org/10.1007/s10900-014-9841-y

[34] Mukherjee S, Sharmasarkar B, Kumar Das K, Bhattacharyya A, Animesh Deb A. Compliance to anti-diabetic drugs: observations from the diabetic clinic of a medical college in Kolkata, India. J Clin Diagn Res 2013; 7: 661-5. doi: 10.7860/JCDR/2013/5352.2876.

[35] Lee H, Ahn S, Kim Y. Self-care, self-efficacy, and glycemic control of Koreans with diabetes mellitus. Asian Nursing Res 2009; 3: 139-146.

http://dx.doi.org/10.1016/S1976-1317(09)60025-6 